Clinica Chimica Acta, 93 (1979) 419-428

(C) Elsevier/North-Holland Biomedical Press

CCA 10221

\title{
URINARY EXCRETION OF OROTIC ACID, OROTIDINE AND OTHER PYRIMIDINES IN A PATIENT WITH PURINE NUCLEOSIDE PHOSPHORYLASE DEFICIENCY
}

\author{
A.H. VAN GENNIP a , J. GRIFT ${ }^{a}$, P.K. DE BREE ${ }^{\text {b }}$, B.J.M. ZEGERS ${ }^{b}$, J.W. STOOP ${ }^{b}$ and \\ S.K. WADMAN ${ }^{b, *}$ \\ a Children's Hospital, Het Emma Kinderziekenhuis, Spinozastraat 51, Amsterdam (The \\ Netherlands) and ${ }^{\text {b }}$ University Children's IIospital, IIet Wilhelmina Kinderziekenhuis, \\ Nieuwe Gracht 137, Utrecht (The Netherlands)
}

(Received December 8th, 1978)

\section{Summary}

Urinary orotidine and orotic acid have been determined in a patient with purine nucleoside phosphorylase (PNP) deficiency under various dietary and therapeutic conditions. For this purpose a new procedure for the analysis of both compounds has been developed, consisting of prefractionation with Dowex 1 X8, followed by two HPLC steps on a $\mu$ Bondapak $\mathrm{NH}_{2}$ and a $\mu$ Bondapak $C_{18}$ column. With this method normal as well as slightly elevated excretions of orotic acid have been found in our patient. No evidence was obtained for inhibition of OPRT by purine (deoxy)nucleosides as a cause of pyrimidine starvation. A significant increase of urinary orotidine was found after loading with allopurinol. For comparison excretory values in a patient with ornithine transcarbamylase deficiency and also in a patient with orotic aciduria type I are shown. The possible cause of the slight increase in urinary orotic acid in our patient has been discussed.

\section{Introduction}

Since in 1972 Giblett et al. [1] described the first case of a patient with severe combined immunodeficiency disease, lacking adenosine deaminase (ADA) activity in the erythrocytes, a number of similarly affected patients have been reported [2-5]. A few years later [6] the same author described a young girl with a severe, selective cellular immune deficiency, associated with the deficiency in the erythrocytes of another enzyme of purine metabolism, nucleoside phosphorylase (PNP), while ADA activity was normal. The defective immunity was confined to the thymus derived lymphocytes ( $\mathrm{T}$-cells), leaving

\footnotetext{
* To whom correspondence should be addressed.
} 
the bone marrow derived lymphocytes (B-cells) unimpaired. Recently, a second patient with PNP deficiency, and a severely defective T-cell immunity has been described [7]. The excretory pattern of purines is highly characteristic for the enzyme defect [8], but the abnormality of urinary pyrimidines is still open to question. Cohen et al. [9] demonstrated elevated concentrations of orotic acid in a single urine sample of our patient and of Giblett's patient. As a causative factor they assumed a pyrophosphoribosylphosphate ( $P P$-ribose- $P$ ) depletion in some cell types, e.g. T-cells or their precursors, which is not likely, because PPribose- $P$ was found to be increased in the erythrocytes [10]. The authors suggested that the increased orotic aciduria was associated with this hypothetic $P P$-ribose- $P$ depletion in some cell types. Another hypothesis was the inhibition of orotate phosphoribosyltransferase (OPRT) by an abnormal metabolite. In order to test the patient's ability to synthesize orotidine and to elucidate the severity of the orotic aciduria, we developed a chromatographic procedure, which is capable of analyzing both orotic acid and orotidine explicitly. This method is described in detail. Besides we describe the follow-up of the urinary orotic acid, orotidine and other pyrimidines in our patient under various conditions of therapeutical approach. For comparison we also analyzed some urine samples of a patient with secondary orotic aciduria due to ornithine transcarbamylase (OTC) deficiency, and a urine sample of a patient with primary orotic aciduria, due to the combined deficiency of the enzymes OPRT and orotidine$5^{\prime}$-monophosphate decarboxylase (ODC).

\section{Methods}

Screening of the urine for orotic acid and orotidine was performed by twodimensional thin-layer chromatography (TLC) after isolation of the compounds from the urine by anion-exchange column chromatography, as described previously [11]. The dried residue of fraction IV was redissolved in $1.0 \mathrm{ml} 0.1 \mathrm{M}$ $\mathrm{NH}_{4} \mathrm{OH}$.

Quantitative analysis of orotic acid and orotidine was done in fraction IV of the isolation procedure by means of high pressure liquid chromatography (HPLC). A Waters Associates liquid chromatograph, equipped with model M $6000 \mathrm{~A}$ solvent delivery system and model $\mathrm{U} 6 \mathrm{~K}$ loop injector was used (Waters Associates, Inc., Milford, MA, U.S.A.). The apparatus was combined with a Perkin-Elmer model LC-55 UV/VIS spectrophotometric detector with scanning accessory (Perkin Elmer Corp., Maywood, IL, U.S.A.) and an Infotronics CRS 304 integrator.

A 20- $\mu \mathrm{l}$ sample of fraction IV was applied to a $3.9 \mathrm{~mm} \times 30 \mathrm{~cm} \mu$ Bondapak $\mathrm{NH}_{2}$ anion-exchange column (Waters) and eluted isocratically with $5 \mathrm{mM}$ sodium acetate, adjusted to $\mathrm{pH} 4.0$ at $20^{\circ} \mathrm{C}$ with glacial acetic acid. The eluate was continuously monitored at $280 \mathrm{~nm}$. Both compounds were eluted between 6.8 and $8.5 \mathrm{~min}$ (flow rate $2 \mathrm{ml} / \mathrm{min}$ ), and in a second run, this fraction of the eluate was collected. The fraction was evaporated to dryness under reduced pressure at $40^{\circ} \mathrm{C}$, redissolved in $0.1 \mathrm{ml}$ of distilled water and stored at $4^{\circ} \mathrm{C}$ in case of further analyses. A third analysis was performed on a two-column system, in which isolation and separation of orotic acid and orotidine were effected in different columns (as shown schematically in Fig. 1). A 20- $\mu$ l sam- 


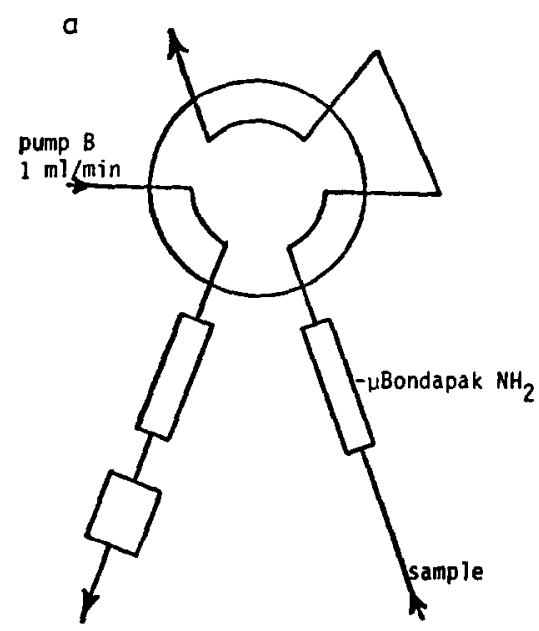

pump A

$1 \mathrm{ml} / \mathrm{min}$

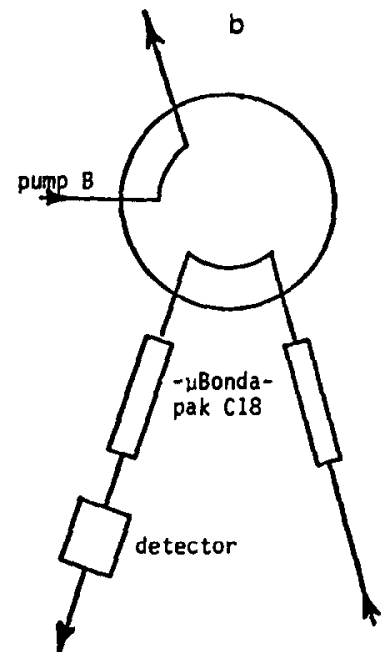

pump $A$

$1 \mathrm{ml} / \mathrm{min}$

I $13.6 \mathrm{~min}$

II $13.6-17.0 \mathrm{~min}$

Fig. 1. Scheme of the dual-column HPLC system used for the analysis of orotic acid and orotidine. Valve: Valvo CV-6-UHPa-N60 Chrompack. (a) Valve switched to position I: both columns eluted separately. (b) Valve switched to position II: both columns connected in series.

ple of fraction IV was applied onto the first column ( $\mu$ Bondapak $\mathrm{NH}_{2}$, Fig. 1a). After 13.6 min just before orotidine together with orotic acid were eluted from the first column, the valve (Valco CV-6-UHPa-N60, Instruments Co., Houston, TX, U.S.A.) was switched so that the second column ( $\mu$ Bondapak $\mathrm{C}_{18}$, reverse phase, $3.9 \mathrm{~mm} \times 30 \mathrm{~cm}$, Waters) was connected in series with the first one.

At 17.0 min when elution of orotidine with orotic acid from the first column was completed, the valve was switched back to its original position (Fig. 1a). For this system the mobile phase was adjusted to $\mathrm{pH} 3.5$ and the flow rate was reduced to $1 \mathrm{ml} / \mathrm{min}$. The eluate of the $\mathrm{C}_{18}$ column was monitored at $280 \mathrm{~nm}$ and at the top of the peaks corresponding with orotidine and orotic acid UV spectra were scanned for confirmation. The spectra were also recorded at $\mathrm{pH}$ $1.1, \mathrm{pH} 5.0$ and $\mathrm{pH}$ 11.1. When, exceptionally, interfering substances were present, $20 \mu \mathrm{l}$ of the concentrate collected from the $\mathrm{NH}_{2}$-column were rechromatographed on the $\mathrm{C}_{18}$ column using the $5 \mathrm{mM}$ sodium acetate-acetic acid buffer pH 4.0 at a flow rate of $2 \mathrm{ml} / \mathrm{min}$. The time of analysis on the two column system can be reduced from 20 to $10 \mathrm{~min}$, if for column I LiChrosorb 10RP $\mathrm{NH}_{2}$, $25 \mathrm{~cm} \times 4.6 \mathrm{~mm}$ ID is chosen (Chrompack, Nederland BV, Middelburg); then the mobile phase is $0.025 \mathrm{M}$ sodium acetate-acetic acid, $\mathrm{pH} 4.0\left(20^{\circ} \mathrm{C}\right)$. Flow rate $2.0 \mathrm{ml} / \mathrm{min}$.

Calibration curves were prepared and a linear relationship between extinction peak area and concentration was found. For determination of the recoveries, both compounds were added to a pre-analyzed urine. Synthetic orotidine was obtained from ICN Pharmaceuticals, Inc., Cleveland, Ohio and orotic acid 
from Calbiochem AG, Lucerne, Switzerland. Urinary uridine and uracil were determined by cation-exchange column chromatography as described previously [8].

\section{Results}

The separation of orotic acid and orotidine was well possible when only the anion-exchange column was used. However, other compounds interfered with both.

Fig. 2a shows a representative chromatogram of fraction IV. When the eluate containing orotic acid and orotidine, collected between 6.8 and 8.5 min was re-chromatographed on the reverse phase column using the same elution procedure, orotidine and orotic acid were separated from interfering substances (Fig. 2b). Both compounds were eluted from the reverse phase column with retention times of $3.1 \mathrm{~min}$ and $3.6 \mathrm{~min}$ respectively. In Fig. 3, a chromatogram obtained with the dual-column system is shown. Orotidine and orotic acid are well separated and, as confirmed by "peak top UV spectrometry", there was no interference by other substances. The $\mathrm{pH}$ characteristics of the spectra of the urinary orotidine and orotic acid fractions were identical with those obtained from the reference compounds. At $\mathrm{pH} 1.1,3.5,5.0$ and 11.1 the absorbance maxima for orotic acid were at $281,276,276$ and $283 \mathrm{~nm}$, for orotidine 267 , 266,266 and $266 \mathrm{~nm}$ respectively, in agreement with literature [12]. The recoveries of orotidine and orotic acid are satisfactory (see Table I). Small losses occur during the prefractionation and isolation steps. The recovery from the dual column system is complete. Recoveries for the total procedure can even be improved further if the evaporation of the formic acid eluate is replaced by freezedrying.

The results of the investigations in our PNP-deficient patient can be summarized as follows. Table II shows urinary orotidine and orotic acid in our patient with PNP deficiency under various therapeutic conditions. On a free diet (dietary intake of purines: $354 \mathrm{mg}$ daily) the excretion of orotic acid on some days was higher than in 6 control patients (Table III) suffering from infections of the upper respiratory tract, but also excretions at the same level were seen. Orotidine was in the same range as in the controls. Purine restriction coincided with higher orotic acid values.

A slightly restricted diet combined with uridine administration resulted in higher orotic acid values than without uridine. When uridine was given, urinary

TABLE I

RECOVERIES FOR OROTIDINE AND OROTIC ACID $(n=5)$

\begin{tabular}{|c|c|c|c|c|}
\hline \multirow[t]{3}{*}{ Procedure } & \multirow{2}{*}{\multicolumn{2}{|c|}{$\begin{array}{c}\text { \% Recovery } \\
\text { Orotidine }\end{array}$}} & \multirow{2}{*}{\multicolumn{2}{|c|}{ Orotic acid }} \\
\hline & & & & \\
\hline & Mean & Actual range & Mean & Actual range \\
\hline \multirow{2}{*}{$\begin{array}{l}\text { Total procedure with isolation step } \\
\text { Total procedure using dual-column system }\end{array}$} & 86 & $82-92$ & 93 & $92-96$ \\
\hline & 93 & $85--106$ & 94 & $90-98$ \\
\hline
\end{tabular}




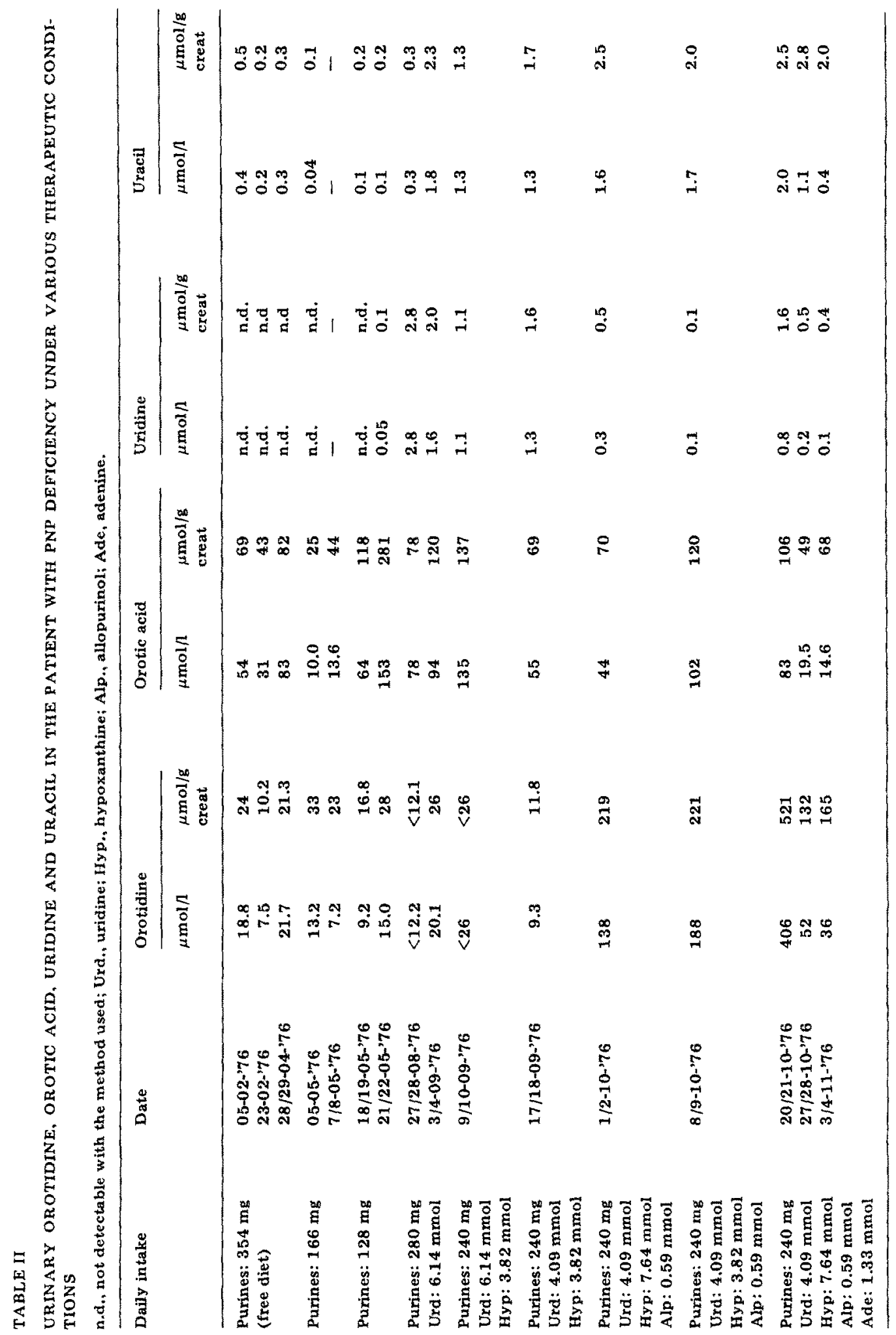






Fig. 2. Fraction IV from urine of patient R.V. with PNP deficiency. (a) Orotidine (I) and orotic acid (II) separated on column I ( $\mu$ Bondapak $\mathrm{NH}_{2}$ ), still containing interfering substances. (b) Orotidine (I) and orotic acid (II) separated on column II $\left(\mu\right.$ Bondapak $\left.\mathrm{C}_{18}\right)$ from interfering compounds III and IV.

Fig. 3. Separation with the dual-column HPLC system of urinary orotidine (I) and orotic acid (II) from our patient with PNP deficiency during loading with uridine, hypoxanthine, adenine and allopurinol (20/21-10-76).

\section{TABLE III}

URINARY OROTIDINE AND OROTIC ACID IN SIX CONTROL PATIENTS SUFFERING FROM RECURRENT INFECTIONS OF THE UPPER RESPIRATORY TRACT

\begin{tabular}{|c|c|c|c|c|c|c|c|}
\hline \multirow[t]{2}{*}{ Subject } & \multirow{2}{*}{$\begin{array}{l}\text { Age } \\
\text { (yrs) }\end{array}$} & \multicolumn{3}{|c|}{ Orotidine } & \multicolumn{3}{|c|}{ Orotic acid } \\
\hline & & $\mu \mathrm{mol} / 1$ & $\mu \mathrm{mol} / \mathrm{g}$ creat & $\mu \mathrm{mol} / 24 \mathrm{~h}$ & $\mu \mathrm{mol} / 1$ & $\mu \mathrm{mol} / \mathrm{g}$ creat & $\mu \mathrm{mol} / 24 \mathrm{~h}$ \\
\hline K.T. & 5.9 & 25 & 31 & 13 & 13.1 & 16.3 & 6.8 \\
\hline C.P. & 0.8 & 14.6 & 15.5 & 2.0 & 8.0 & 8.5 & 1.1 \\
\hline $\mathbf{I} . \mathbf{R}$. & 2.8 & 15.3 & 61 & 11.6 & 5.9 & 21 & 4.5 \\
\hline B.R. & 1.9 & 26 & 53 & 5.1 & 20.3 & 42 & 4.0 \\
\hline O.K. & 0.3 & 12.5 & 53 & 4.4 & 6.4 & 27 & 2.2 \\
\hline M.C. & 2.1 & 9.0 & 18.6 & 3.1 & 3.9 & 11.9 & 1.9 \\
\hline
\end{tabular}

TABLE IV

URINARY URIDINE AND URACIL IN SIX CONTROL PATIENTS SUFFERING FROM RECURRENT INFECTIONS OF THE UPPER RESPIRATORY TRACT

\begin{tabular}{|c|c|c|c|c|c|c|c|}
\hline \multirow[t]{2}{*}{ Subject } & \multirow{2}{*}{$\begin{array}{l}\text { Age } \\
\text { (yrs) }\end{array}$} & \multicolumn{3}{|l|}{ Uridine } & \multicolumn{3}{|l|}{ Uracil } \\
\hline & & $\mu \mathrm{mol} / \mathrm{l}$ & $\mu \mathrm{mol} / \mathrm{g}$ creat & $\mu \mathrm{mol} / 24 \mathrm{~h}$ & $\mathrm{mmol} / \mathrm{l}$ & $\mathrm{mmol} / \mathrm{g}$ creat & $\mathrm{mmol} / 24 \mathrm{~h}$ \\
\hline K.T. & 5.9 & $<33$ & $<10$ & $<2$ & 0.06 & 0.08 & 0.03 \\
\hline C.P. & 0.8 & $<44$ & $<50$ & $<5$ & 0.07 & 0.07 & 0.01 \\
\hline J.R. & 2.8 & $<7$ & $<20$ & $<8$ & 0.09 & 0.30 & 0.07 \\
\hline B.R. & 1.9 & $<7$ & $<10$ & $<2$ & 0.05 & 0.09 & 0.01 \\
\hline O.K. & 0.3 & $<7$ & $<30$ & $<4$ & 0.04 & 0.16 & 0.01 \\
\hline M.C. & 2.1 & $<7$ & $<20$ & $<5$ & 0.03 & 0.09 & 0.02 \\
\hline
\end{tabular}


TABLE V

URINARY OROTIDINE, OROTIC ACID, AND URACIL IN THE PATIENT WITH PNP DEFICIENCY ON TREATMENT WITH TRANSFUSIONS OF IRRADIATED RED CELLS (IRC) ALONE OR COMBINED WITH ORAL ADMINISTRATION OF DEOXYCYTIDINE AND YEAST

If peaks of orotidine were inhomogenous the notation < is used. Uridine was not detectable with the method used.

\begin{tabular}{|c|c|c|c|c|c|c|}
\hline \multirow[t]{2}{*}{ Treatment and date } & \multicolumn{2}{|c|}{ Orotidine } & \multicolumn{2}{|c|}{ Orotic acid } & \multicolumn{2}{|l|}{ Uracil } \\
\hline & $\mu \mathrm{mol} / 1$ & $\begin{array}{l}\mu \mathrm{mol} / \mathrm{g} \\
\text { creat }\end{array}$ & $\mu \mathrm{mol} / 1$ & $\begin{array}{l}\mu \mathrm{mol} / \mathrm{g} \\
\text { creat }\end{array}$ & $\mathrm{mmol} / 1$ & $\begin{array}{l}\mathrm{mmol} / \mathrm{g} \\
\text { creat }\end{array}$ \\
\hline \multicolumn{7}{|l|}{ IRC } \\
\hline 23-12-76 & 1.4 & 2.3 & 2.6 & 4.2 & 0.11 & 0.18 \\
\hline $06-01-77$ & $<15.2$ & $<18.4$ & 8.7 & 10.5 & 0.18 & 0.22 \\
\hline 12/13-01-'77 & $<19.4$ & $<21$ & 12.8 & 14.1 & 0.26 & 0.29 \\
\hline 03-02-77 & $<26.0$ & $<27$ & 19.9 & 21 & 0.14 & 0.15 \\
\hline 16/17-02-'77 & 8.7 & 10.8 & 5.4 & 6.8 & 0.16 & 0.20 \\
\hline 17-02-'77 & 6.0 & 13.7 & 4.1 & 9.3 & 0.09 & 0.21 \\
\hline 23/24-11-'77 & 12.2 & 16.4 & 26 & 35 & 0.11 & 0.15 \\
\hline \multicolumn{7}{|l|}{$\begin{array}{l}\text { ICR + deoxycytidine } \\
\text { (0.77 mmol per day) }\end{array}$} \\
\hline $7 / 8-12-77$ & 15.0 & 17.2 & $\mathbf{3 4}$ & 39 & 0.13 & 0.15 \\
\hline 21/22-1 2-'7 7 & 13.9 & 16.2 & 34 & 39 & 0.14 & 0.16 \\
\hline $4 / 5-01$-78 & 10.0 & 17.0 & 25 & 42 & 0.10 & 0.17 \\
\hline 19/20-01-'78 & 13.8 & 21 & 31 & 48 & 0.14 & 0.22 \\
\hline $2 / 3-02-' 78$ & 16.1 & 42 & 34 & 88 & 0.10 & 0.26 \\
\hline $16 / 17-02-' 78$ & 12.5 & 17.6 & 23 & 33 & 0.12 & 0.17 \\
\hline $02-03-978$ & 14.7 & 16.4 & 31 & 35 & 0.28 & 0.31 \\
\hline
\end{tabular}

uracil was also increased (see Tables II and IV). The addition of hypoxanthine or adenine to the diet had no effect, but allopurinol increased the orotidine excretion drastically. During enzyme replacement therapy with irradiated red cells (Table V), orotic acid and orotidine were in the same range as in the controls. During addition of deoxycytidine $(0.77 \mathrm{mmol} /$ day $)$ and yeast, orotic acid increased again to the free diet level. In Table VI the excretory values of oroti-

\section{TABLE VI}

URINARY OROTIDINE, OROTIC ACID, URIDINE AND URACIL IN A PATIENT WITH ORNITHINE TRANSCARBAMYLASE DEFICIENCY (A.v.d.R.) AND A PATIENT WITH THE SEQUENTIAL DEFICIENCY OF THE ENZYMES OROTATE PHOSPHORIBOSYLTRANSFERASE AND OKOTIUINE-5'MONOPHOSPHATE DECARBOXYLASE (D.G.)

n.d., not detectable with the method used.

\begin{tabular}{|c|c|c|c|c|c|c|c|c|}
\hline \multirow[t]{2}{*}{ Subjects and data } & \multicolumn{2}{|c|}{ Orotidine } & \multicolumn{2}{|c|}{ Orotic acid } & \multicolumn{2}{|l|}{ Uridine } & \multicolumn{2}{|l|}{ Uracil } \\
\hline & $\mu \mathrm{mol} / \mathrm{l}$ & $\begin{array}{l}\mu \mathrm{mol} / \mathrm{g} \\
\text { creat }\end{array}$ & $\mu \mathrm{mol} / 1$ & $\begin{array}{l}\mu \mathrm{mol} / \mathrm{g} \\
\mathrm{creat}\end{array}$ & $\mathrm{mmol} / 1$ & $\begin{array}{l}\text { mmol } / \mathrm{g} \\
\text { creat }\end{array}$ & $\mathrm{mmol} / 1$ & $\begin{array}{l}\mathrm{mmol} / \mathrm{g} \\
\text { creat }\end{array}$ \\
\hline \multicolumn{9}{|l|}{ A.v.d.R. } \\
\hline $23-10-70$ & $<11.1$ & 77 & 1641 & 11317 & 1.3 & 8.9 & 1.0 & 6.8 \\
\hline $9 / 10-11-' 70$ & $<25$ & 73 & 395 & 1145 & n.d. & n.d. & 0.2 & 0.6 \\
\hline 20-12-71 & $<16.6$ & $<21$ & 1397 & 1735 & 1.3 & 1.7 & 1.4 & 1.8 \\
\hline 2/3-08-'72 & $<15.0$ & $<60$ & 2237 & 8948 & 0.7 & 2.7 & 0.5 & 2.0 \\
\hline 26-02-73 & n.d. & n.d. & 1397 & 3139 & 0.8 & 1.7 & 0.8 & 1.8 \\
\hline \multicolumn{9}{|l|}{ D.G. } \\
\hline 12/3-'77 & 34 & 79 & 2205 & 5128 & 0.05 & 0.1 & 0.1 & 0.2 \\
\hline
\end{tabular}


dine and orotic acid in a patient with OTC-deficiency (5 samples), and in a patient with the combined deficiency of OPRT and ODC (orotic aciduria type I) are given. Urinary orotidine was in the same range as in our patient with PNP deficiency but orotic acid was much higher. Also urinary uridine and uracil in these patients were much higher than in the patient with PNP deficiency (see Tables II and VI).

\section{Discussion}

The quantitative determination of urinary orotic acid and orotidine is complicated by the interference of other urinary constituents. In literature many methods are reported for orotic acid including enzymatic methods [13], colorimetric methods without [14] and with preceding extraction $[15,16]$, partition column chromatographic procedures $[16,17]$, anion- $[18,19]$ and cationexchange column chromatography [20], and an isotope dilution procedure [21]. For orotic acid and orotidine both time consuming HPLC methods have been described, using anion-exchange columns, gradient elution and UV detection [22--25].

In the method used by Cohen et al. [9], HPLC of the urine is performed before and after treatment with OPRT and ODC, and the concentration of the compounds calculated by subtraction of the results obtained in the two analyses. No orotidine was detected in the urine of two patients with PNP deficiency. However, with the method described here, we did find orotidine in our own patient, though at a normal level. Using this method we had the opportunity of studying orotic aciduria and orotidinuria in detail in this patient. The application of the dual-column method is not necessarily limited to the analysis of orotidine and orotic acid, but offers wide possibilities in HPLC analysis.

The increased orotic aciduria reported by Cohen et al. [9] did not appear to be a constant phenomenon. On a free diet (daily dietary intake of purines $354 \mathrm{mg}$ ) orotic acid was within the normal range as well as slightly elevated, whereas the excretion of the purine (deoxy)nucleosides did not change strikingly in the same period. This argues against an inhibition of OPRT by one of the accumulating (deoxy)nucleosides. Also the fact that the addition of uridine to the diet did not reduce either urinary orotic acid or orotidine, argues against an inhibition of OPRT, although it is possible that the uridine did not reach the presumed OPRT-deficient tissues.

However, the striking increase in the excretion of orotidine during loading with allopurinol leads us to definitely rejecting the theory of inhibition of OPRT by accumulating substances. Enzyme replacement therapy with irradiated red cells reduced the excretion of orotic acid to the control level. Nucleosides and deoxynucleosides decreased rhythmically as a result of the therapy, but did not normalize. This means that (deoxy)nucleosides are not the direct cause of the orotic aciduria. Pyrimidine starvation due to the inhibition of OPRT seems not likely, because in that case a normalization of urinary orotic acid following supplementation with uridine and deoxycytidine should be expected. On the contrary, after the supplementations, the level of the orotic aciduria was rather increased than decreased. However, orotic aciduria is not expected to be reduced by the administration of pyrimidine (deoxy)nucleosides 
in the presence of normal OPRT- and ODC-activities. Probably in our patient, the slight increase in orotic acid results from an elevated pyrimidine de novo synthesis.

A strikingly increased synthesis of pyrimidines leading to excessive urinary excretion of orotic acid, uridine and uracil is shown in a patient with OTC deficiency (Table VI). However, orotidine was always normal. Occasionally in our patient with OTC deficiency, urinary orotic acid was as high as in a patient with hereditary orotic aciduria type I on treatment with uridine. In this disease there is a block at the levels of both OPRT and ODC, resulting in pyrimidine deprivation and absence of end product repression of enzyme synthesis and negative feedback control, in which the pyrimidine nucleotides suppress the activity of one or more enzymes acting early in pyrimidine synthesis, especially carbamyl phosphate synthetase.

The possibility of inhibition of OTC by CTP and other nucleotides [26] may be considered. This inhibition might lead to hyperammonemia and increased orotic aciduria. However, hyperammonemia has not been observed in our patient. Very recently, Cohen et al. [27] reported elevated deoxyguanosine triphosphate (deoxy-GTP) levels in the erythrocytes of the PNP-deficient patients.

Since deoxy-GTP is a known inhibitor of cytidine-diphosphate- and uridinediphosphate reductase in mammalian cells [28], it is speculated that in PNPdeficient patients abnormally high levels of deoxy-GTP in the T-lymphocytes might cause deprivation of deoxycytidine triphosphate (deoxy-CTP) and deoxyuridine triphosphate (deoxy-UTP) resulting in inhibition of DNA synthesis. If this is so, also elevated levels of CDP, UDP, CMP and UMP in these cells may be expected. UMP $[29,30]$ is known to inhibit the ODC-OPRT enzyme complex competitively. Possibly CMP has the same effect [30]. This may be the most likely explanation of the increased orotic aciduria in our patient after supplementation with uridine and deoxycytidine.

\section{References}

1 Giblett, E.R., Anderson, J.E., Cohen, F., Pollara, B. and Meuwissen, H.J. (1972) Lancet ii, 1067

2 Dissing, J. and Knudsen, B. (1972) Lancet ii, 1316

3 Ochs, H.D., Yount, I., Giblett, F.R., Chen, S.H., Scott, C.R. and Wedgwood, R.J. (1973) Lancet ii, 133

4 Yount, J., Nichols, P., Ochs, H.D., Hammar, S.P., Scott, C.R., Chen, S.H., Giblett, E.R. and Wedgwood, R.J. (1974) J. Pediatr. 84, 173.

5 Wara, D.W. and Ammann, A.J. (1975) in Combined Immuno-deficiency and Adenosine Deaminase Deficiency. A Molecular Defect (Meuwissen, H.J., Pollara, B., Pickering, R.J. and Porter, I.H., eds.), p. 249, Academic Press, New York

6 Giblett, E.R., Amman, A.J., Wara, D.W., Sandman, R. and Diamond, L.K. (1975) Lancet i, 1010

7 Stoop, J.W., Zegers, B.J.M., Hendrickx, G.F.M., Siegenbeek-van Heukelom, L.H., Staal, G.E.J., de Bree, P.K., Wadman, S.K. and Ballieux, R.E. (1977) N. Engl. J. Med. 296, 651

8 Wadman, S.K., de Bree, P.K., Van Gennip, A.H., Stoop, J.W., Zegers, B.J.M., Staal, G.E.J. and Siegenbeck-van Heukclom, L.H. (1077) in Purinc Metabolism in Man II: Regulation of Pathways and Enzyme Defects (Müller, M.M., Kaiser, E. and Seegmiller, J.E., eds.), p. 471, Plenum, New York

9 Cohen, A.. Staal, G.E.J., Ammann, A.J. and Martin, D.W., Jr. (1977) J. Clin. Invest. 60, 491

10 Siegenbeek-van Heukelorn, L.H.. Akkerman, J.W.N., Staal, G.E.J., de Bruyn, C.H.M.M., Stoop, J.W., Zegers, B.J.M., de Bree, P.K. and Wadman, S.K. (1977) Clin. Chim. Acta 74, 271

11 Van Gennip, A.H., Van Noordenburg-Huistra, D.Y., de Bree, P.K, and Wadman, S.K. (1978) Clin. Chim. Acta 86, 7

12 Rauen, H.M. (1964) Biochemisches Taschenbuch, Vol. I, pp. 609 and 875, Springer Verlag, Berlın 
13 Rosenbloom, F.M. and Seegmiller, J.E. (1964) J. Lab. Clin, Med. 63, 492

14 Golovinsky, E. (1968) Z. Chem. 8, 421

15 Rogers, L.E. and Porter, F.S. (1968) Pediatrics 42, 423

16 Kesner, L., Aronson, F.L., Silverman, M. and Chan, P.C. (1975) Clin. Chem. 21, 353

17 Kesner, L. (1974) in Clinical Biochemistry (Curtius, H.Ch. and Roth, M., eds.), Vol, 2, pp. 14011405, Walter de Gruyter, New York

18 Becroft, D.M.O., Phillips, L.I. and Simmonds, A. (1969) J. Pediatr. 75, 885

19 Bellinger, J.F. and Buist, N.R.M. (1971) Clin. Chem. 17, 1132

20 Bonnelycke, B.E., Dus, K. and Miller, S.L. (1969) Anal. Biochem. 27, 262

21 Christopherson, R.I. and Finch, L.R. (1977) Anal. Biochem. 80, 159

22 Jolley, R.L. and Scott, C.D. (1970) Clin. Chem. 16, 687

23 Kelley, W.N. and Wijngaarden, J.B. (1970) Clin. Chem. 16, 707

24 Beardmore, T.D. and Kelley, W.N. (1971) Clin. Chem. 17, 795

25 Mrochek, J.E., Butts, W.C., Rainey, W.T., Jr, and Burtis, C.A. (1971) Clin. Chem. 17.72

26 Rennert, O.M. (1977) Ann. Clin. Lab. Science 7, 262

27 Cohen, A., Gudas, L.J., Ammann, A.J., Staal, G.E.J. and Martin, D.W., Jr. (1978) J. Clin. Invest. 61, 1405

28 Moore, E.C. and Hurlbert, R.B. (1966) J. Biol. Chem. 241, 4802

29 Blair, D.G.R. and Potter, V.R. (1961) J. Biol. Chem. 236, 2503

30 Brown, G.K. and O'Sullivan, W.J. (1977) Biochem. Pharmacol, 26, 1947 